\title{
O CYWILIZACJI ROSYJSKIEJ \\ WEDŁUG ALEKSANDRA DUGINA - NAJNOWSZE BADANIA
}

Marcin SkıAdanowski, Cywilizacja rosyjska wedtug Aleksandra Dugina. Studia historyczno-antropologiczne, Lublin: Towarzystwo Naukowe KUL 2019, ss. 206

Książka Marcina Składanowskiego podejmuje niezwykle ciekawy i ważny temat dotyczący współczesnych zmagań cywilizacyjnych i ideowych w świecie. Rosja wciąż stanowi kluczowy podmiot na kontynencie eurazjatyckim, posiadający ogromną potęgę militarną. Postrzeganie świata, wojen cywilizacyjnych przez elity rosyjskie wydaje się tematem niezwykle ważnym dla zrozumienia celów polityki rosyjskiej, a także metod ułożenia stosunków społecznych w tym kraju. Analiza myśli Aleksandra Dugina nadaje się do takich analiz w sposób wyjątkowy. Myśliciel ten od lat ma ogromny wpływ na sposób myślenia rosyjskich elit politycznych. $\mathrm{Z}$ drugiej strony jest to twórca nietuzinkowy; stara się on swoje rozważania osadzać w szerokim kontekście rosyjskiej historii i rosyjskiej myśli politycznej. Wielu analityków zadaje sobie cały szereg pytań dotyczących Rosji, np. o sposób łączenia tradycji imperialnej epoki carskiej oraz komunistycznego Związku Radzieckiego we współczesnej propagandzie ekipy Władimira Putina. W myśli Dugina z pewnością znaleźć można cały szereg odpowiedzi na te nurtujące pytania. Dobór tematu rozprawy wydaje się zatem bardzo trafny.

Marcin Składanowski nie skupia się w swoich rozważaniach na powierzchownym opisie myśli imperialnej Dugina, którą zainteresowany jest w szczególności świat polityki i mediów. Idzie o wiele głębiej w swych badaniach, próbując dać odpowiedź na kluczowe pytanie, o podstawy sakralizacji państwa rosyjskiego, o wizję Rosji zdefiniowanej jako osobnej cywilizacji. Niezwykle wartościowe są opisy dotyczące miejsca religii prawosławnej w rosyjskiej przestrzeni cywilizacyjnej.

Książka od strony źródłowej oparta jest na różnorodnej podstawie. Autor wykorzystał wszystkie niezbędne do analizy dzieła Aleksandra Dugina, sięgnął do pozycji podejmujących intelektualną refleksję nad jego twórczością, wreszcie odniósł się do dziedzictwa rosyjskiej myśli politycznej, a także dorobku myślicieli zachodnich. 
Wielka szkoda, że autor pominął dorobek polskiej nauki. Spośród refleksji intelektualnej świata Zachodu na temat cywilizacji rosyjskiej dorobek nauki polskiej wydaje się najbardziej istotny. Wielowiekowe doświadczenia współegzystencji oraz walki militarnej, kulturowej i cywilizacyjnej obu narodów zaowocowały niezwykle doniosłymi publikacjami naukowymi w tym zakresie. Składanowski często odnosi tezy Dugina do zachodnich teoretyków cywilizacji, w szczególności do Samuela Huntingtona ${ }^{1}$. Jest to $\mathrm{w}$ pełni uzasadnione $\mathrm{z}$ uwagi na globalną konfrontację Rosji i USA. Myśl amerykańska, w tym twórczość Huntingtona mocno oddziałuje na geopolitykę i geostrategię na całym świecie. Odniesienie rosyjskiej wizji imperialnej do poglądów najgłośniejszych analityków amerykańskich wydaje się niezwykle inspirujące, od strony warsztatowej wręcz konieczne. Nie ulega jednak wątpliwości, że Amerykanie o wiele płycej postrzegają pewne zjawiska dziejące się w Rosji niż Polacy, bardziej obeznani z czymś, co zwiemy potocznie „duszą rosyjską”. Marcin Składanowski nie wykorzystał dzieł największego dzisiaj w Polsce znawcy Rosji, Andrzeja Nowaka (Uniwersytet Jagielloński)². Brak jest również odniesienia do klasyków polskich, takich jak Jan Kucharzewski ${ }^{3}$. Zupełnie jednak niezrozumiałe jest pominięcie myśli Feliksa Konecznego ${ }^{4}$, twórcy polskiej szkoły teorii cywilizacji. Koneczny poświęcił w swojej twórczości mnóstwo miejsca na Rosję, opisując szeroko wpływy cywilizacyjne w tym wielkim imperium. Jego spojrzenie na ten kraj wydaje się w wielu miejscach o wiele głębsze niż myślicieli zachodnich (w tym Huntingtona). Zaczerpnięcie z dzieł Konecznego z pewnością uczyniłoby książkę Składanowskiego od strony merytorycznej jeszcze bogatszą. Brak odniesień do myśli koneczniańskiej musi dziwić jeszcze z jednego powodu: w Katolickim Uniwersytecie Lubelskim Jana Pawła II wytworzyła się cała szkoła filozoficzna, podejmująca krytyczną refleksję nad teorią cywilizacji (autor z pewnością zna dorobek tej szkoły, wszak wywodzi się z KUL-u). Chodzi oczywiście o przedstawicieli Lubelskiej Szkoły Filozoficznej, której założycielem był o. prof. Mieczysław Albert Krąpiec. Cywilizacyjną myślą Konecznego zajmował się sam Krąpiec oraz cała plejada jego uczniów. Wystarczy wymienić Henryka Kieresia, Piotra Jaroszyńskiego (cały szereg analiz prowadzonych było w czasopiśmie „Człowiek w Kulturze” redagowa-

1 S. Huntington, The Clash of Civilizations and the Remaking of World Order, London: Simon \& Schuster 2002.

2 A. NowaK, Metamorfozy Imperium Rosyjskiego 1721-1921, Kraków: Wydawnictwo Literackie 2018.

3 J. Kucharzewski, Od białego do czerwonego caratu, t. I-VII, Warszawa: Wydawnictwo Naukowe PWN 1998-2000.

4 F. Koneczny, Dzieje Rosji, Krzeszowice: Ostoja 2015. 
nym przez prof. Jaroszyńskiego) ${ }^{5}$, wreszcie Pawła Skrzydlewskiego ${ }^{6}$ oraz Ryszarda Polaka ${ }^{7}$. W dorobku tej szkoły mamy nie tylko prostą prezentację myśli Konecznego, lecz jej ogromne ubogacenie poprzez odniesienie do klasycznej myśli filozoficznej (nurt arystotelesowsko-tomistyczny). Sięgnięcie do tego dorobku z pewnością dałoby autorowi recenzowanej pozycji ogromne narzędzia do skutecznej oceny myśli cywilizacyjnej Aleksandra Dugina z perspektywy prawdziwościowej.

Składanowski wskazuje też na specyficzne zdefiniowanie przez Dugina kwestii metodologii uprawianej przez niego nauki. Dugin odżegnuje się od metod właściwych dla tradycji zachodniej (s. 69). Szkoda, że autor nie wykazał tutaj sprzeczności. Wszak Dugin wchodząc w dyskurs z myślą zachodnią, czyni to posługując się (przynajmniej do pewnego stopnia) klasyczną logiką czy też klasyczną definicją prawdy. Inaczej nie byłby w stanie wykazywać błędów w myśleniu politologów i geostrategów zachodnich. Tak naprawdę nie da się zrezygnować z klasycznych odniesień metodologicznych (początki nauki są przecież w Europie), gdyż mają one zakorzenienie w ludzkiej racjonalności. Inaczej mielibyśmy do czynienia tylko i wyłącznie z woluntarystyczną deklaracją ideologiczną, niewchodzącą w dyskurs z ideowymi przeciwnikami. A Dugin w taki dyskurs wchodzi. Negując Zachód, tak czy inaczej musi posługiwać się zachodnią racjonalnością.

Marcin Składanowski słusznie wskazuje, że Dugin „nie jest ideologiem Kremla”, choć deklarował takie pragnienia. Współczesna, postkomunistyczna elita polityczna Rosji jest w ogromnej masie bezideowa i w sposób czysto utylitarny wykorzystuje dorobek ludzi takich jak Dugin (s. 12-13). Tym niemniej reprezentuje on bardzo silny typ rosyjskiego kierunku imperialnego, którym państwo rosyjskie się posługuje. Wykłady w rosyjskiej Wojskowej Akademii Sztabu Generalnego, Moskiewskim Uniwersytecie Państwowym im. Łomonosowa pokazują znaczenie Dugina dla rosyjskich służb (s. 25). Geopolityka duginowska rozumiana jako suma nieustannych walk cywilizacji Lądu i Morza (s. 31-36) ukazuje z kolei, że Dugin staje się dobrym narzędziem do prowadzenia przez Rosję wielkiej eurazjatykiej gry o dominację.

Autor recenzowanej pozycji opisał inspiracje ideowe Dugina, jego intelektualną i polityczną drogę. Precyzyjnie ukazane zostały odniesienia filozoficzne (Nietzsche, Eliade itd.). Taki opis był konieczny, aby myśli Dugina osadzić w szerokim kontekście ideowym Europy i świata (s. 22). W innym miejscu ukazane zostały skomplikowane odniesienia religijne (czerpanie $\mathrm{z}$ heterodoksyjnej historiozofii i eschatologii

5 Por. „Człowiek w Kulturze”, 1998, nr 10.

6 P. Skrzydlewski, Polityka w cywilizacji łacińskiej, Lublin: Fundacja Rozwoju Kultury Polskiej 2002.

7 R. Polak, Cywilizacje a Moralność w myśli Feliksa Konecznego, Lublin: Fundacja Servire Veritati Instytut Edukacji Narodowej 2001. 
starowierców) (s. 26). Chrześcijaństwo Dugina Składanowski określa: „względne i wybiórcze" (s. 28) - co jest diagnozą niezwykle celną. Zdefiniowanie Rosji jako dziedziczki Złotej Ordy stanowi jednoznaczne opowiedzenie się Dugina po stronie Azji - nie tyle w sensie geopolitycznym, ile cywilizacyjnym. Składanowski udowodnił, że taki sposób myślenia Dugina prowadzi do spozycjonowania religii do roli prymitywnego narzędzia w rękach państwa (s. 54-55). Ważne jest wykazanie w książce manichejskiego postrzegania świata (s. 76) w imperialnej myśli rosyjskiej, zasadniczo od strony teologicznej nie do pogodzenia z klasycznym chrześcijaństwem.

Składanowski skutecznie wykazał znaczenie Azji w myśli duginowskiej - pozytywnego odniesienia do tradycji Chin, Indii, Iranu, Mongolii w celu uzasadnienia antyokcydentalizmu (s. 38). Wskazał tu również na korzenie rosyjskiego, antyokcydentalnego słowianofilstwa w XIX wieku ${ }^{8}$. Cenne jest wydobycie z myśli Dugina wizji Rosji jako „oryginalnej i samodzielnej cywilizacji” (s. 43). Autor osadza teorie cywilizacyjne bohatera swojej książki w konfrontacji z tezami najgłośniejszych myślicieli amerykańskich (S. Huntington Zderzenie cywilizacji, F. Fukuyama Koniec historii ${ }^{9}$ ) (s. 44-45). Jest to ważne z wielu względów: poznawczych - mamy tutaj pokazanie imperialnej rosyjskiej refleksji geopolitycznej na tle dorobku intelektualnego przedstawicieli supermocarstwa amerykańskiego; politycznych - takie skonfrontowanie myśli Dugina pokazuje odmienność celów geostrategicznych USA i Rosji w realnej polityce eurazjatyckiej. Doskonale ilustruje to domaganie się przez Dugina specjalnego miejsca dla Rosji w nowym ładzie sił w układzie globalnym (s. 48-49).

W dalszej części pracy autor przeanalizował cechy cywilizacji rosyjskiej lansowanej przez Dugina: ponadczasowość, niepojmowalność, agrarność, prawosławie (pojmowane w sensie kulturowym i społecznym, a nie teologicznym), tradycjonalizm (s. 70-81). Cechy te Składanowski opisuje w sposób interesujący i szeroki, wyjaśniając bardzo dużo z tego, co zwiemy „rosyjską duszą”. Niezwykle trafne oceny dotyczą miejsca prawosławia w państwie rosyjskim (sakralizacja państwa, religia jako narzędzie stosowane do zabiegu takiej sakralizacji) (s. 75).

Niedosyt pozostawia kwestia oceny poglądów Dugina od strony prawdziwościowej. Składanowski nieco ucieka od jednoznacznych ocen tego myślenia. Jest to skutek pominięcia w rozważaniach przez autora aspektu filozoficznego, ale rozumianego nie w kontekście historycznym, ale rzeczowym. Odniesienie do klasycznej filozofii (Krąpiec) dałoby autorowi potężne narzędzia do tego, aby dokonać dogłębnej krytyki zredukowania człowieka w koncepcji duginowskiej do rangi trybu w wielkiej machinie imperialnego państwa. Wszak sam autor pisze o tym, że Dugin

8 Zob. analiza myśli Nikołaja J. Danilewskiego (s. 64-68).

9 F. Funuyama, The End of History and the Last Man, New York: Free Press 2006. 
„nie tylko podważa zachodnią koncepcję człowieka, opartą na godności osoby ludzkiej i rozumieniu praw człowieka jako praw indywidualnych za nieodpowiednią czy kulturowo obcą Rosji, lecz wzywa do całkowitego odrzucenia zachodnich wartości, takich jak demokracja, indywidualna wolność czy gospodarka wolnorynkowa" (s. 90-91). Odrzucenie godności osoby ludzkiej, naturalnych praw człowieka to wszak prosta droga do totalitaryzmu, krytykowanego po wielokroć przez zachodnich badaczy (historyków, socjologów, politologów, etyków itp.). Autor recenzowanego dzieła mógłby również się pokusić o taką krytykę. Oczywiście jest to niemożliwe bez oparcia się na twardych podstawach filozoficznych. Stąd ponawiam mój postulat sięgnięcia po dorobek Lubelskiej Szkoły Filozoficznej lub chociażby do myśli Feliksa Konecznego, tak mocno krytykującego „cywilizacje gromadnościowe", sprowadzające człowieka do roli trybu w wielkiej machinie państwowej. W myśli Dugina można wykazać wiele sprzeczności. Krytykuje on np. zachodni darwinizm społeczny (s. 101), sam odwołując się do azjatyckiej przemocy, która ma jednoznaczne cechy bezwzględnej walki o byt. Wydaje się, że takiej krytycznej refleksji w książce Składanowskiego mogłoby być więcej.

Powyższe uwagi dotyczące książki Marcina Składanowskiego nie zmieniają wysokiej oceny tego dzieła, które zawiera w sobie dużą wartość poznawczą oraz ma wielkie znaczenie społeczne. Bez znajomości myśli Aleksandra Dugina trudno zrozumieć dzisiejszą Rosję w jej sposobie funkcjonowania na gruncie społecznym, w jej poczynaniach na eurazjatyckiej szachownicy. Opisując „,rosyjską misję dziejową" prezentowaną przez Dugina, Składanowski wiele wyjaśnia zachodniemu czytelnikowi, ukazując meandry „azjatyckiej duszy rosyjskiej”. Tylko w ten sposób jesteśmy w stanie pojąć rosyjskie sprzeczności: afirmację tradycyjnego prawosławia oraz sowieckiego dziedzictwa imperialnego; odniesienia do tradycji bizantyjskiej a zarazem mongolskiej. Czytając książkę Składanowskiego możemy też lepiej zrozumieć trudną nieraz do zaakceptowania niechęć elit rosyjskich do łacińskiej tradycji Zachodu, w tym Polski.

BIBLIOGRAFIA

„Człowiek w Kulturze”, 1998, nr 10.

Funuyama F., The End of History and the Last Man, New York: Free Press 2006.

Huntington S., The Clash of Civilizations and the Remaking of World Order, London: Simon \& Schuster 2002.

Koneczny F., Dzieje Rosji, Krzeszowice: Ostoja 2015.

Kucharzewski J., Od białego do czerwonego caratu, t. I-VII, Warszawa: Wydawnictwo Naukowe PWN 1998-2000.

NowaK A., Metamorfozy Imperium Rosyjskiego 1721-1921, Kraków: Wydawnictwo Literackie 2018. 
PolaK R., Cywilizacje a Moralność w myśli Feliksa Konecznego, Lublin: Fundacja Servire Veritati Instytut Edukacji Narodowej 2001.

SkıADAnowski M., Cywilizacja rosyjska wedlug Aleksandra Dugina. Studia historyczno-antropologiczne, Lublin: Towarzystwo Naukowe KUL 2019.

Skrzydlewski P., Polityka w cywilizacji łacińskiej, Lublin: Fundacja Rozwoju Kultury Polskiej 2002.

Mieczystaw Ryba Katedra Świata Hiszpańskiego, Polityki i Relacji Międzynarodowych KUL e-mail:lipin@kul.lublin.pl 